\title{
Pelatihan Pasca Panen dan Pengolahan Jambu Biji Merah untuk Petani di Kecamatan VII Koto Sungai Sariak Padang Pariaman
}

\author{
Wenny Surya Murtius dan Purnama Dini Hari \\ Fakultas Teknologi Pertanian, Universitas Andalas, Kampus Limau Manis, Padang, 25163. Indonesia \\ E-mail:wenny.murtius@gmail.com
}

Keywords:

guava, post

harvest,

processing, farmer

Kata Kunci:

jambu biji merah, nilai tambah, pasca panen, pengolahan, petani

\begin{abstract}
Community service activities carried out in District VII Koto Sungai Sariak, Padang Pariaman Regency. Partners who act as training participants were red guava's farmers who already have a garden and have harvested. Priority problems faced by partners were not yet understanding about post-harvest handling and processing of red guava. The training method was participatory, where the activity was carried out by providing training and conducting joint processing practices. The results of the activity showed that the participants were very enthusiastic in participating in the training and included joint practices. So after the training the participants had understood the techniques of post-harvest handling and processing of red guava into several products. Post-harvest handling delivered include picking methods, handling after picking, and primary and secondary packaging used. The processing practice carried out during the training was the manufacture of red guava jam. The expectation of this activity is the implementation of appropriate post-harvest handling and the availability of processed guava products in Kecamatan VII Koto Sungai Sariak, Padang Pariaman Regency.
\end{abstract}

\footnotetext{
ABSTRAK

Kegiatan pengabdian kepada masyarakat ini dilaksanakan di Kecamatan VII Koto Sungai Sariak Kabupaten Padang Pariaman. Mitra sebagai peserta pelatihan adalah petani jambu biji merah yang telah memiliki kebun dan telah panen. Permasalahan prioritas yang dihadapi mitra adalah belum memahami tentang penanganan pasca panen dan pengolahan jambu biji merah. Metode pelatihan adalah partisipatif, dimana kegiatan dilakukan dengan cara memberikan pelatihan dan melakukan praktik pengolahan secara bersama. Hasil kegiatan menunjukkan bahwa peserta sangat antusias mengikuti pelatihan dan setelah pelatihan peserta telah memahami teknik penanganan pasca panen dan pengolahan jambu biji merah menjadi beberapa produk. Penanganan pasca panen yang disampaikan diantaranya metode petik, penanganan setelah di petik, serta pengemasan. Praktik pengolahan yang dilakukan pada saat pelatihan adalah pembuatan selai jambu biji merah. Harapan dari kegiatan ini adalah terlaksananya penanganan pasca panen yang tepat dan tersedianya produk olahan jambu biji merah di Kecamatan VII Koto Sungai Sariak Kabupaten Padang Pariaman.
} 


\section{PENDAHULUAN}

Pembudidayaan jambu biji merah di Kabupaten Padang Pariaman sudah dilakukan semenjak tahun 2000. Hingga saat ini Kabupaten Padang Pariaman sudah mempunyai varietas unggul untuk komoditi ini yang terus dikembangkan. Akan tetapi selama ini jambu biji merah hanya dijual dalam bentuk segar, namun proses panen dan sehingga mereka memiliki keinginan untuk melakukan pengolahan ataupun hanya untuk memperpanjang kesegaran dari jambu biji segar, jika dikirim keluar daerah. Karena kegiatan pertanian yang mereka jalani belum menunjukkan peningkatan perekonomian yang nyata dalam keluarga.

Jambu biji merah yang apabila dikirim keluar daerah dalam keadaan segar (waktu beberapa hari), akan cepat rusak atau membusuk. Sedangkan Teknik panen dan penanganan pasca panen serta pengolahan jambu biji merah ini belum dilakukan dengan optimal, karena banyak dari petani belum mengetahui cara yang tepat untuk penanganan hal tersebut. Dinas Pertanian dan Ketahanan Pangan Kabupaten Padang Pariaman, sebagai pendamping kelompok tani berkeinginan untuk mengadakan penyuluhan dan pelatihan terhadap beberapa kelompok tani pembudidaya jambu biji merah. Usaha budidaya jambu biji merah yang dilakoni petani, diharapkan tidak hanya menghasilkan jambu biji segar melainkan juga melakukan pengolahan terhadap jambu biji tersebut. Karena semakin tinggi value add dari suatu produk akan semakin dihargai konsumen. Selanjutnya penulis bertindak sebagai narasumber pada kegiatan ini.

Jambu biji merah merupakan tanaman hortikultura yang bersifat perishable, sehingga perlu upaya pengolahan. Idawanni (2016) menjelaskan produk hortikultura segar juga sangat mudah mengalami kerusakan yaitu kerusakan fisik akibat berbagai penanganan yang dilakukan. Kerusakan fisik ini terjadi karena secara fisik-morfologis, produk hortikultura segar mengandung air tinggi (85-98\%) sehingga benturan, gesekan dan tekanan sekecil apapun dapat menyebabkan kerusakan yang dapat langsung dilihat secara kasat mata dan dapat tidak terlihat pada saat aktifitas fisik tersebut terjadi. Pengetahuan tentang teknik pasca panen dan pengolahan jambu biji merah diharapkan dapat memberi nilai tambah terhadap komoditi ini, sehingga dapat meningkatkan pendapatan petani.

Tujuan program yang dijalankan adalah peserta memahami tentang penanganan pasca panen jambu biji merah serta mengetahui beberapa cara pengolahan jambu biji merah. Daerah yang telah menjadi sentra produksi jambu biji merah ini, diharapkan menjadi daya tarik tersendiri bagi konsumen untuk mencari jambu biji merah segar beserta olahannya.

\section{METODE}

Pengabdian kepada masyarakat dilaksanakan di Kecamatan VII Koto Sungai Sariak. Metode yang diterapkan dalam pelaksanaan program pengabdian kepada masyarakat ini adalah partisipatif dalam bentuk penyuluhan tentang teknik pasca panen jambu biji merah, dimana semua pihak terkait akan terlibat sepenuhnya pada kegiatan ini. Jumlah peserta pada kegiatan ini ada sejumlah 36 orang, peserta yang terlibat merupakan peserta yang aktif dan dipilih oleh Dinas Pertanian dan Ketahanan Pangan Kabupaten Padang Pariaman.

Kegiatan ini diperuntukkan bagi kelompok tani jambu biji merah. Selanjutnya akan dilakukan evaluasi dan pendampingan, karena program ini bertujuan untuk terus berjalan walaupun pemograman telah selesai. Adapun bentuk kegiatan yang dilaksanakan adalah: a). Program teknik pasca panen yang tepat, b). Program pelatihan pengolahan jambu biji merah, c). Program Penerapan sanitasi selama pengolahan, d). Pembelajaran tentang pemasaran, dan e). Evaluasi 


\section{HASIL DAN PEMBAHASAN}

Berdasarkan kegiatan yang telah dilaksanakan, dimana kegiatan dimulai dengan pembukaan oleh tim pendamping kelompok tani Dinas Pertanian, Peternakan dan Kehutanan Kabupaten Padang Pariaman, dilanjutkan dengan penyuluhan, penyuluhan dibagi menjadi beberapa sesi, diantaranya adalah penyampaian materi dan diskusi. Kegiatan selanjutnya adalah pengolahan jambu biji merah yang dilakukan secara bersama, dimana seluruh peserta dilibatkan dalam berbagai kegiatan, hingga menghasilkan produk olahan jambu biji merah. Selama kegiatan berlangsung peserta terlihat sangat antusias mengikuti pelatihan dan praktek. Saat diskusi berlangsung, berkembang sangat alot dengan berbagai pertanyaan yang dilontarkan mitra. Mulai dari teknik pasca panen sampai pada pengolahan, diskusi juga terus berlanjut selama praktik pengolahan yang dilakukan. Suasana penyuluhan seperti terlihat pada Gambar 1.

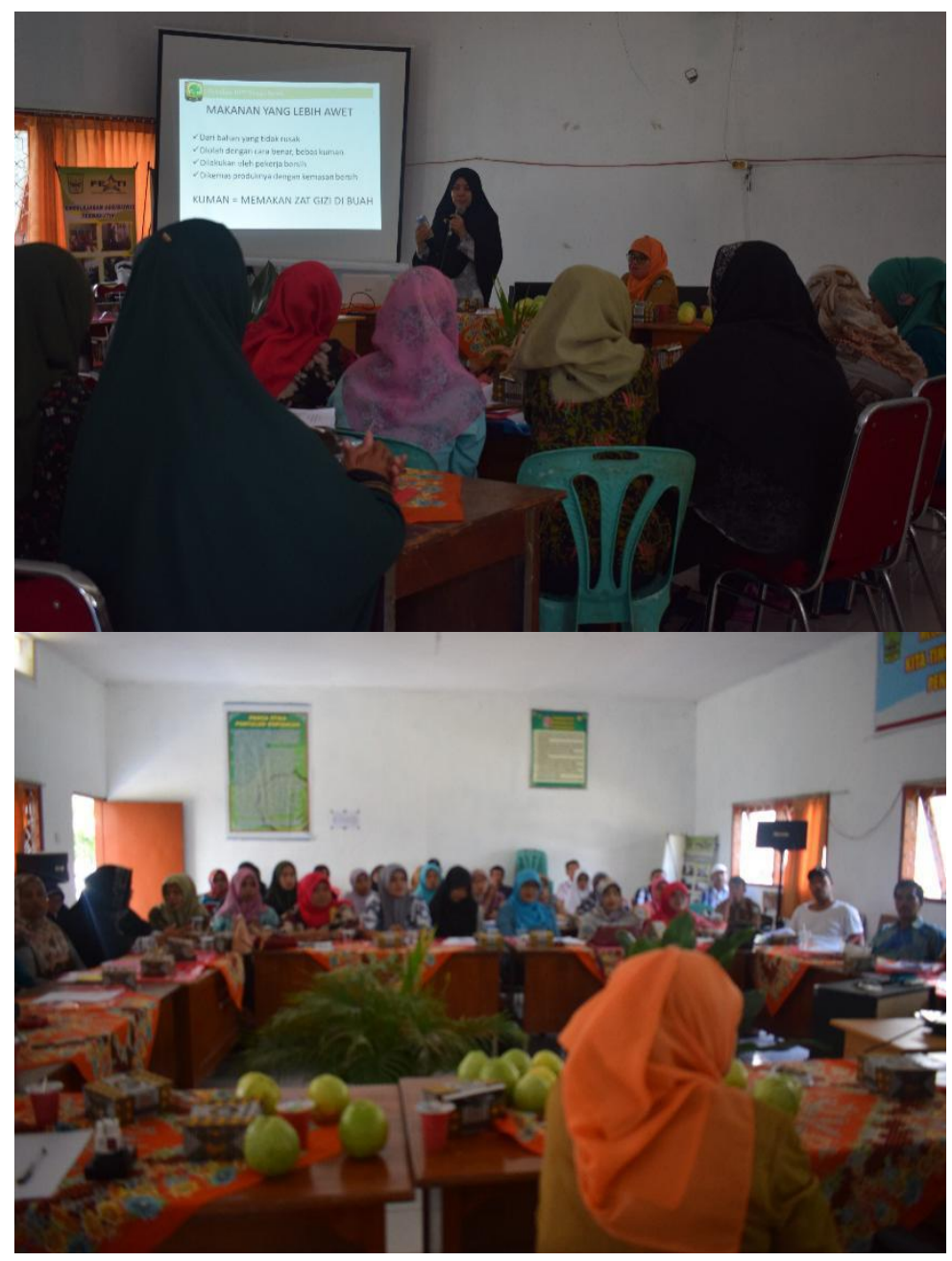

Gambar 1. Suasana penyuluhan

Materi yang disampaikan selama penyuluhan adalah materi yang berkaitan dengan teknik panen, pasca panen, pengemasan dan kemasan yang digunakan untuk buah segar, dan beberapa pengolahan jambu biji merah. Suasana penyuluhan seperti pada Gambar 1. menunjukkan keingintahuan peserta tentang teknik panen, pasca panen, dan pengolahan jambu biji merah. Diantara materi yang penting disampaikan pada penyuluhan adalah:

\section{Teknik Panen}

Yang perlu diperhatikan saat proses pemanenan: 1. Umur petik (adapun ciri buah siap panen: warna hijau kekuningan dan mengkilap). 2. Proses panen (buah dipanen menggunakan gunting buah, tangkai buah sepanjang $3 \mathrm{~cm}$ dipotong dan ikut bersama buah). 3 . Pendinginan (yang dimaksud pendinginan ini adalah pelepasan panas kebun, caranya dengan menaruh buah 
di bawah tajuk tanaman dulu, tujuan : menurunkan metabolisme buah) 4. Penggunaan wadah untuk membawa hasil panen ke gudang (buah dibawa ke gudang menggunakan keranjang, keranjang diisi sesuai ukuran, untuk menghindari luka dan memar pada buah).

\section{Pasca Panen}

Buah jambu biji yang bermutu punya ciri yaitu berat buah lebih dari $250 \mathrm{~g}$, kulit buah terlihat mulus, tidak ada luka dan memar, tidak ada bercak, dan buah masih ada tangkainya. Buah bermutu bagus harus dipisahkan dari yang kurang bagus, dengan alasan: buah yang bagus seharusnya dihargai lebih mahal, buah yang bagus bisa masuk ke pasar yang lebih baik, mencampur buah bagus dan rusak akan mempercepat kerusakan buah yang bagus. Terdapat 4 tingkat mutu buah jambu biji, yakni Grade A: Buah beratnya diatas $250 \mathrm{~g}$, tampilan bagus, ada tangkai buah, Grade B: Buah beratnya 151 - 249 g, tampilan bagus, ada tangkai buah, Grade C: Berat dibawah 100 - $150 \mathrm{~g}$, tampilan bagus, ada tangkai buah, dan Grade D: Berat dibawah 100 g, memar dan bercak

Beberapa hal sangat penting diperhatikan untuk menghindari penurunan grade dari buah segar jambu biji merah. Hal yang bisa menyebabkan buah luka dan memar dan menjadi lembek antara lain:
a. Menumpuk buah membentuk gunungan di lantai
b. Melempar-lempar buah saat mengelompokkan
c. Memadatkan buah dalam keranjang
d. Memadatkan buah dalam kotak saat akan dikirim

\section{Kemasan yang Baik}

Penggunaan kotak karton atau kayu untuk kemasan buah segar sudah baik. Yang terpenting jangan dipadatkan isinya. Dilapisi kertas sebelum disusun agar pernapasan buah menurun. Jangan sampai bersinggungan antar buah, untuk menghindari kontak fisik dan kerusakan fisik buah.

\section{Pengolahan Buah Jambu Biji}

Pengolahan jambu biji merah penting dilakukan karena berbagai pertimbangan, diantaranya:

a. Memanfaatkan buah yang tidak terjual saat panen raya.

Pada saat panen raya, buah yang tersedia akan sangat banyak, hal ini sudah pasti menjadikan buah yang sudah dipanen akan tersimpan lama (belum terjual dalam bentuk segar). Jika buah disimpan terlalu lama, akan menyebabkan buah menjadi busuk dan tidak bisa dikonsumsi lagi. Buah jambu biji merah seperti inilah yang dapat dimanfaatkan untuk diolah, sehingga tidak ada buah yang terbuang percuma.

b. Memanfaatkan buah grade rendah.

Buah grade rendah harganya sudah pasti rendah juga atau bahkan bisa jadi tidak ada pembeli. Untuk menghindari buah terbuang dan atau dijual murah, maka dengan pengolahan yang diterapkan diharapkan dapat meningkatkan nilai jual buah jambu biji merah tersebut.

c. Menaikkan nilai jual buah grade rendah.

Hal ini sejalan dengan pemanfaatan buah grade rendah.

d. Memperpanjang umur simpan.

Jambu biji merah yang termasuk buah klimaterik, yang terus melangsungkan pernafasan setekah panen, yang menyebabkan buah cepat rusak dan busuk, sudah pasti memiliki umur simpan yang pendek. Biasanya sekitar 1-2 minggu, dalam keadaan waktu panen yang tepat, cara panen dan pasca panen (penyimpanan) yang sesuai. Bila dalam waktu tersebut buah belum dikonsumsi atau tidak terjual, sudah pasti tidak bisa digunakan lagi.

Sedangkan dengan pengolahan yang diterapkan, memanfaatkan teknologi yang ada, diharapkan dapat menjadikan produk yang diolah menjadi tahan lama. 
Beberapa hal yang menjanjikan dari jambu biji merah.

a. Buah jambu biji merah kaya vitamin $\mathrm{C}$.

Kadar vitamin C pada jambu biji merah, menjadikan komoditi ini banyak digemari. Namun, keberadaan vitamin $\mathrm{C}$ pada bahan baku memerlukan perhatian khusus selama pengolahan, terlebih lagi pemanasan dengan suhu yang tinggi akan menyebabkan kerusakan vitamin $\mathrm{C}$ dan tidak bisa dimanfaatkan lagi (hilang).

b. Buah jambu biji merah warnanya menarik, yaitu merah lembut. Bisa coklat setelah pemanasan.

Warna merupakan salah satu yang menjadi daya tarik bagi konsumen. Keberadaan warna merah yang menarik pada jambu biji merah tidak hanya menjadikannya lebih menarik, melainkan menandakan bahwa terdapat suatu senyawa yang bersifat sebagai antioksidan pada buah jambu biji merah tersebut. Zat warna merah tersebut, juga dapat mengalami kerusakan (warnanya berubah menjadi kecoklatan, yang dikenal dengan reaksi browning). Sehingga hal tersebut sangat penting untuk diperhatikan selama pengolahan.

c. Buah jambu biji mengandung pektin. Banyak olahan pangan yang bagus dibuat dari buah berpektin.

Pektin merupakan salah satu senyawa yang menjadikan buah jambu biji merah menjadi komoditi dengan berbagai pengolahan yang bisa dilakukan Karena banyak produk olahan yang selama pengolahan membutuhkan senyawa ini. Bahkan pada sebagian produk sengaja menambahkan pektin sewaktu pengolahan, supaya produk olahan jadi. Contohnya dalam pembuatan selai, selai lembaran dan permen jelly. Namun pada bahan baku seperti jambu biji merah tidak memerlukan penambahan pektin karena sudah tersedia secara alami pada jambu biji merah.

Akhir dari pelatihan yang dilakukan adalah kegiatan praktik bersama peserta, salah satu pengolahan yang di praktikkan adalah pembuatan selai jambu biji merah. Pada saat praktik berlangsung semua peserta diikutsertakan atau terlibat secara langsung, diadakan tanya jawab dan diskusi mengenai praktik yang sedang berlangsung. Peserta tertarik dengan praktik yang dilakukan, karena pembuatan selai jambu biji merah merupakan hal yang baru bagi mereka. Selama kegiatan berlangsung juga dijelaskan apasaja yang menjadi titik kritis atau yang mempengaruhi keberhasilan. Beberapa hal yang perlu diperhatikan adalah cara menentukan lama pemasakan, dimana metode spoon test diterapkan dalam hal ini. Suhu yang digunakan adalah suhu yang tidak menyebabkan kerusakan terlalu banyak terhadap warna dan Vit. C pada jambu biji merah. Gambar 3 merupakan suasana praktik pengolahan dan Gambar 4. Pendinginan selai jambu biji merah.

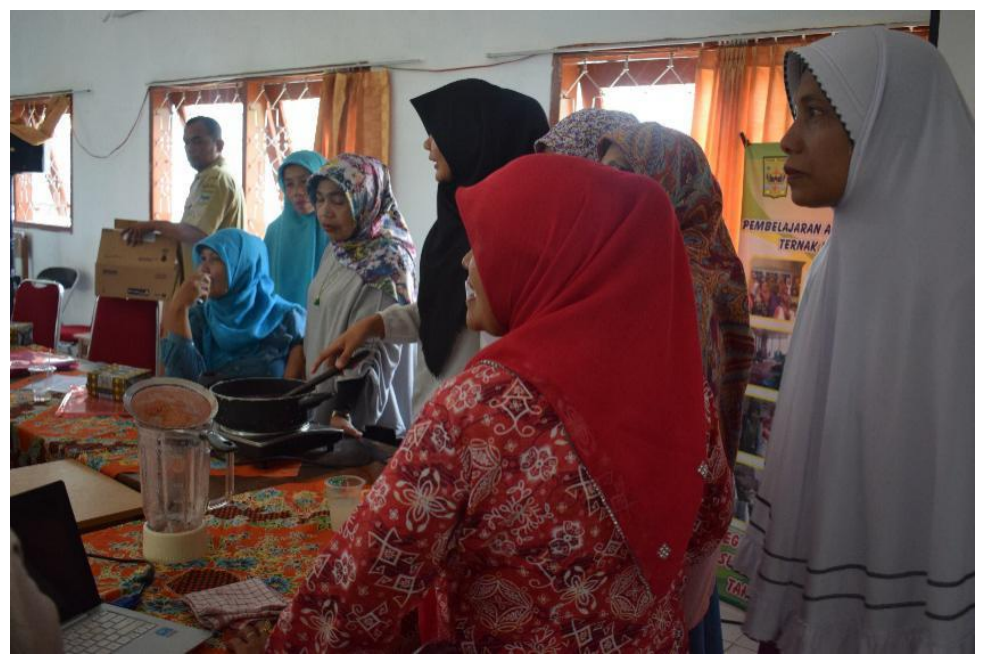

Gambar 2. Praktik pengolahan selai dari Jambu Biji Merah 


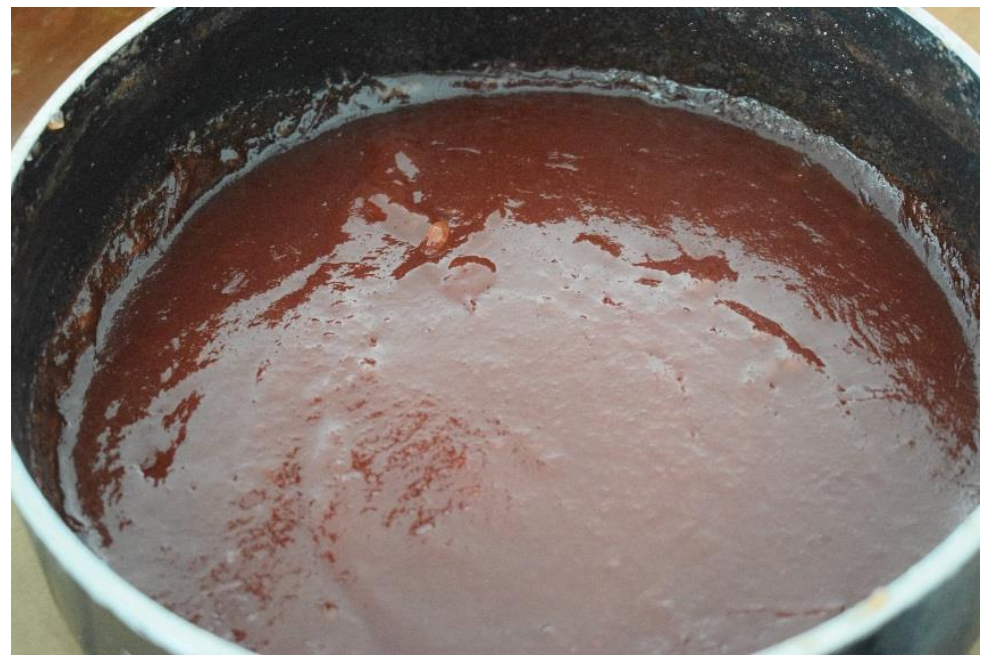

Gambar 3. Pendinginan selai Jambu Biji Merah setelah dimasak

\section{KESIMPULAN}

Berdasarkan kegiatan yang telah dilakukan terlihat ketertarikan peserta pada kegiatan yang berlangsung, peserta pelatihan telah memiliki bekal mengenai teknik pasca panen jambu biji merah serta mengetahui pengolahan jambu biji merah menjadi produk unggulan. Harapan dari kegiatan ini adalah terlaksananya penanganan pasca panen yang tepat dan tersedianya produk olahan jambu biji merah di Kecamatan VII Koto Sungai Sariak Kabupaten Padang Pariaman.

\section{UCAPAN TERIMA KASIH}

Terima kasih penulis sampaikan pada Dinas Pertanian dan Ketahanan Pangan Kabupaten Padang Pariaman yang telah menfasilitasi untuk terlaksananya kegiatan pengabdian kepada masyarakat ini.

\section{DAFTAR PUSTAKA}

Admin. 2008. Profil Kecamatan Ulakan Tapakis. https://ulakantapakis.wordpress.com. (diakses 31 Mei 2018).

Badan Pusat Statistik (BPS) Kabupaten Padang Pariaman. 2017. VII Koto Sungai Sariak dalam Angka 2017. https://padangpariamankab.bps.go.id. ISSN / ISBN:978-602-6365-33-0 (diakses 7 Mei 2018).

Idawanni. 2016. Pasca Panen Buah Jambu Biji (Psidium guajava, L). http://nad.litbang.pertanian.go.id/ind/index.php/info-teknologi/798-pasca-panen-buahjambu-biji-psidium-guajava-l (diakses 12 Januari 2019).

Indriyani, N.L.P. 2016. Jambu Biji Piraweh Ampalu dari Padang Pariaman. https://balitbu.litbang.pertanian.go.id (diakses 7 Mei 2018).

Soekarto, S.T. 1985. Penilaian Organoleptik untuk Industri Pangan dan Hasil Pertanian. Bhatara Karya Aksara. Jakarta. 